\title{
Fun English language learning for Kids
}

\author{
Yuli Choirul Umah \\ STAI Miftahul Ula Nganjuk \\ riyu.choirul57@gmail.com
}

\begin{abstract}
Currently, the English language introduction in elementary school, where subjects are not too needed for children, but for the author himself has a different opinion. For English writers need to be introduced to children. The introduction of English for children is certainly in a way that is different from secondary school children, such as JUNIOR and HIGH school. The introduction of English for children with the intent of not burdensome, does not make the child bored, packaged in the form of play while studying, or even the sense of not learning but play that gives them English skills. Singing, games, drawing, coloring, storytelling, and more are effective methods for introducing English to children.
\end{abstract}

Keyword : Fun, English language, learning, Kids

\section{INTRODUCTION}

Learning the language in the minds of people says it's an easy thing, because they consider that every day we already use the language. Learning a language is not just the bias we communicate with the language but also to know and understand the meaning contained in the word. Language is the voice used by every nation to reveal its meaning. So the language is a voice expression produced by the tool movement and captured by the ears. The phases of language development begin from screams, screaming then systematic raving through impersonation and teaching. Early childhood gained language proficiency very quickly and almost without harsh effort in the period of the first three or four years (Gleason, 1988). According to Bjorklund (2005) The development of language skills related to speech development, the more capable people speak the richer the ability of language, the richer the ability to make children more confident to speak. At the time of preschool language skills are developing rapidly, along with the need to socialize and curiosity of children. In fact they are also easier to learn languages other than mother tongue, compared to adults. Thus teaching English as a foreign language is more appropriate when done as early as possible. The critical/sensitive period for language learning is in early childhood, where the flexibility of the brain is still excellent. The development of language skills will underlie the ability to read, the richer the vocabulary is owned, the easier the child understands the writing, and ultimately the smoother the ability of the child to read (Amitya: 2012). 


\section{DISCUSSION}

\section{Singing (Songs)}

Singing is a series of words that dilagukan with a certain rhythm and tone. With the singing of the song, teachers can invite students to do activities that are closely related to the daily life of the child.

Singing other than as an activity that can bring its own fun for children, can also develop the imagination and self-confidence of the child, so that stimulate the child to be more creative and bold to appear in the public, the ability of children in singing at this early age Usually based on his experience when listening to music or hearing the parents and the people around him singing.

The song was created with the main objectives:

1. The song that was created just to be enjoyed and

2. The song was created with learning objectives.

Songs and rhythms are an important part of children's lives and are also a tool or as a medium of language learning to children. I.e. teaching and learning especially foreign languages, learning a language through singing makes children feel happy in learning because they love songs, while singing they actually learn English.

The songs created for children's learning have the following traits:

1. Contains words, phrases, or sentences with a specific theme.

2. Language elements are repeated.

3. Generally the singing is context so easily memorized.

4. Songs by the movements of the Limbs (action songs)

5. songs can be sung outside the class by the child.

6. Happy Pitada.

In teaching English with the song, a teacher needs to pay attention to some important things, among others as follows:

1. Choose songs that correspond to the student's characteristics and level of language development.

2. The lyrics of the song are not too long so it is not difficult to memorize.

3. Songs should be interesting, dynamic, and joyous.

4. For certain purposes, for example, the teacher wants to teach a specific language item, then choose a song that contains repetition of the language grain.

5. In choosing a song, it is worth considering the use of simple and easy spoken words.

6. A short hymn with simple, joyful words will quickly be eliminated by the children. 


\section{Example: Song 1}

As an introduction, Twinkle song, Little star guru can explain or ask the students in advance about the meaning of star. After students have a clear concept, then the teacher can invite the children to sing together.

What is a star?

A star : is a small twinkling light

We sometimes see in the night time sky

Stars are far from the earth. The sun

Is a special star that we can see during

The day. A star is also a kind of shape.

\section{Song}

Twin-kle, twin-kle lit-tle star. How I won-der what you are !

Up a-bove the world so high. Like a dia-mond in the sky.

Twin-kle, twin-kle lit-tle star. How I won-der what you are !

\section{Game}

Games are activities performed based on specific rules. Children play because they are happy. Children learn through the game. By the time they play together, the child interacts with each other. In such interactions, language skills can be built, especially listening and speaking.

Play is interpreted by many experts in various ways, for example:

1. According to Schiller and Spencer, that child has an excess of energy, and that energy can be expressed through playing activities.

2. According to Karl Groos, through playing activities, a child prepares himself for his future life if he is an adult.

3. According to Tanley Hall, by playing the children through the same stages of development of the History of Mankind (recapitulation theory).

4. According to Lazarus, that children play to rebuild the lost energy. (In Anita Yus, 2005).

Some meanings of the game method are:

1. Learning by playing method is learning by Seolah-olah way in a situation to gain an understanding of a concept. In this method students are actively engaged so that it will better understand the concept and longer remember, but takes a long time.

2. The game method is a way of teaching that is implemented in the game.

3. The game method in learning is a way to convey lessons with the means of playing. The gameplay in learning can give students an opportunity to be directly involved in learning and to make students feel happy about the lesson. From the explanation above can be concluded that the method of the game is a teaching method where the presentation of material with the game. So with the 
game unknowingly by the child/learners that they have been treated to a lesson. In addition, to further stimulate the interest of children learn. Using simple language that is easy to understand, so they are easier to learn and receive explanations from their education and parents. The game Method (games), known by various designations such as heating (ice-breaker) or refreshment (energizer). The literal meaning of ice-breaker is ' ice breaker '. So, the meaning of heating in the learning process is a situation solver mind or physical the participant. The game is also meant to build a dynamic, passionate, and passionate learning atmosphere.

According to some experts experience, communicative language games have six traits, namely the following:

1. The game must interact with each other.

2. The all games must understand the rules in the game.

3. The game must have a clear purpose.

4. The context of its activities is clear.

5. The players must be actively involved.

6. Players get special rules in play.

In performing a learning with a game it is important to remember that a teacher must first give direction to the students, what should be done clearly. Students have to really understand first with what to do.

Here are some examples of games that can be done for lower class children are as follows:

1. Simon says

The teacher asks the students to perform actions.

Teacher: "Simons says sit down".

(Student seated)

"Simon says put your hands on your head"

(Students put hands on his head)

"Simon Clap Your Hands".

(Students applauded)

Students do what teachers say

2. Question Answer

The game trains a specific pattern of sentences and there are elements competing between students and other groups. For example, what is the sentence pattern?. Students are divided into two groups, then race to give answers.

Example: guess what fruit?

Teacher: It's yellow. It's long. It's sweet.

What is it?

Students: It is.... (A banana)

Teacher: It's red. It's round. It's sweet. 
What is it?

Students: It is.....

Then when it is smooth, the teacher's position can be played by children. Can also students and one group prepare questions for another group. Students must use the sentence pattern already studied or that they are learning using a familiar vocabulary.

3. Guessing Games

The teacher shows the small parcel and asks the students to guess what is in the parcel. It's very good to train yes/no question.

Example:

Students: Is it a toy?

Teacher: No, it is'nt.

Students: Is it chocolate?

Teacher: No it is'nt.

Students: Can you eat?

Teacher: Yes, I can.

4. Find Differences

Activities undertaken by students to train the accuracy of students in pairs or groups. Two pictures were given to the students and they were asked to look for some of the differences in the image using familiar English vocabulary. They can also ask the teacher or look for a dictionary.

5. Wisper Game

a. Students sit lined or circular

b. The teacher whispered something (a word or phrase) to the first student. For example, are you hungry?

c. The student continues by whispered the same phrase to his friend to be forwarded to the other.

d. Promptings are only one time and cannot be repeated.

e. The last student will reveal the word or phrase in a loud voice. The first student also said in a loud voice, to know whether the phrase that the last student heard was the same as the first student.

f. The situation will make students laugh if if the sentence spoken by the last student is very different from the sentence that the student heard first. 4

\section{CONCLUSION}


Singing is a series of words that dilagukan with a certain rhythm and tone. With the singing of the song, teachers can invite students to do activities that are closely related to the daily life of the child.

The song was created with the main objectives: 1) Songs created just to be enjoyed and 2) The song is created with learning objectives.

Games are activities performed based on specific rules. Children play because they are happy. Children learn through the game. By the time they play together, the child interacts with each other. In such interactions, language skills can be built, especially listening and speaking. Some examples of games that can be done: Simon Says, Question Answer, Games, Find Differences, Whisper Game.

\section{REFERENCES}

Djamarah, Syaiful Bahri dan Zain Aswan. 2010. Stategi belajar Mengajar. Jakarta : Rineka Cipta

Kasihani K.E Suyanto. 2008. English For Young Learners. Jakarta: Bumi Aksara.

Semiawan, : 2003 Paradigma Baru Pendidikan Anak Dini Usia, Bumi Aksara, Jakarta.

http://fitrirohmawati.blogspot.com/2013/12/metode-pembelajaran-padapendidikan.html 